\title{
High Entropy Alloys Prepared by Combination of Mechanical Alloying and Spark Plasma Sintering
}

Filip Průša, Alexandra Šenková, Dalibor Vojtěch, Jaroslav Čapek, Adriana Bernatiková

Department of Metals and Corrosion Engineering, University of Chemistry and Technology Prague. Technická 5, 16628 Prague. Czech Republic. E-mail: prusaf@vscht.cz

High entropy alloys belongs to quite novel materials that are attracting far more attention throughout the entire materials research. They are characterized by wide range of unique properties e.q. ultra-high strength while maintaining its ductility, good corrosion resistance, wear resistance, thermal stability, magnetic properties and many others. Generally, they are composed at least by five elements with nearly eqiatomic compositions that are further characterized by high mixing entropy allowing only formation of solid solutions. The investigated CoCrFeNiMn high entropy alloy was prepared by powder metallurgy processes combining the mechanical alloying with hightech compaction via spark plasma sintering. The microstructure of prepared compact alloy was examined by the optical microscopy and electron scanning microscopy with EDS detector. The chemical and phase composition was determined by the results of the XRF analysis and by X-ray diffraction analysis. Prepared alloy reached ultrahigh compressive yield strength of $1570 \mathrm{MPa}$ and hardness $352 \mathrm{HV} 30$ outperforming the cast alloy with identical chemical composition that reached only $230 \mathrm{MPa}$ and $120 \mathrm{HV} 30$, respectively.

Keywords: Mechanical alloying; microstructure; hardness; high entropy alloys.

\section{Acknowledgement}

The authors wish to thank the Czech Science Foundation (project no. P108/12/G043) for its financial support of this research.

\section{References}

[1] HE, F., WANG, Z; ; et al. Designing eutectic high entropy alloys of CoCrFeNiNbx. In: Journal of Alloys and Compounds, Vol. No., pp.

[2] CHEN, Z., CHEN, W.; et al. (2015). Effects of Co and Ti on microstructure and mechanical behavior of Al0.75Fe$\mathrm{NiCrCo}$ high entropy alloy prepared by mechanical alloying and spark plasma sintering. In: Materials Science and Engineering: A, Vol. 648, No., pp. 217-224.

[3] FU, Z., CHEN, W.; et al. (2015). Effects of Co and sintering method on microstructure and mechanical behavior of a high-entropy Al0.6NiFeCrCo alloy prepared by powder metallurgy. In: Journal of Alloys and Compounds, Vol. 646, No., pp. 175-182.

[4] LIU, W.H., HE, J.Y.; et al. (2015). Effects of Nb additions on the microstructure and mechanical property of CoCrFeNi high-entropy alloys. In: Intermetallics, Vol. 60, No., pp. 1-8.

[5] SINGH, S., WANDERKA, N.; et al. (2011). Decomposition in multi-component AlCoCrCuFeNi high-entropy alloy. In: Acta Materialia, Vol. 59, No. 1, pp. 182-190.

[6] HE, J.Y., ZHU, C.; et al. (2014). Steady state flow of the FeCoNiCrMn high entropy alloy at elevated temperatures. In: Intermetallics, Vol. 55, No., pp. 9-14.

[7] CHUANG, M.-H., TSAI, M.-H.; et al. (2011). Microstructure and wear behavior of AlxCo1.5CrFeNi1.5Tiy highentropy alloys. In: Acta Materialia, Vol. 59, No. 16, pp. 6308-6317.

[8] ZHANG, Y., ZUO, T.T.; et al. (2014). Microstructures and properties of high-entropy alloys. In: Progress in Materials Science, Vol. 61, No. 0, pp. 1-93.

[9] SENKOV, O.N., MIRACLE, D.B. (2016). A new thermodynamic parameter to predict formation of solid solution or intermetallic phases in high entropy alloys. In: Journal of Alloys and Compounds, Vol. 658, No., pp. 603-607.

[10] JI, W., WANG, W.; et al. (2015). Alloying behavior and novel properties of CoCrFeNiMn high-entropy alloy fabricated by mechanical alloying and spark plasma sintering. In: Intermetallics, Vol. 56, No., pp. 24-27.

[11] VOJTĚCH, D. (2015). Faculty of Chemical Technology, University of Chemistry and Technology, Prague: Research and Development in the Field of Advanced Metallic Materials. In: Manufacturing Technology, Vol. 15, No. 6, pp. vi-ix.

[12] KUČERA, V., PRŮŠA, F., VOJTĚCH, D. (2016). Processing of Al-Fe Scraps by Powder Metallurgy. In: Manufacturing Technology, Vol. 16, No. 4, pp. 726-732. 
[13] PRŮŠA, F., VOJTECH, D.; et al. (2015). Mechanical alloying: A way how to improve properties of aluminium alloys. In: Manufacturing Technology, Vol. 15, No. 6, pp. 1036-1043.

[14] JI, W., FU, Z.; et al. (2014). Mechanical alloying synthesis and spark plasma sintering consolidation of CoCrFeNiAl high-entropy alloy. In: Journal of Alloys and Compounds, Vol. 589, No., pp. 61-66.

\section{Paper number: M2016250}

Copyright (C) 2016. Published by Manufacturing Technology. All rights reserved. 